\title{
Subnational climate entrepreneurship: innovative climate action in California and São Paulo
}

\author{
Karen Anderton $^{1} \cdot$ Joana Setzer $^{2}$
}

Received: 18 May 2016/Accepted: 18 April 2017 / Published online: 10 June 2017

(C) The Author(s) 2017. This article is an open access publication

\begin{abstract}
The distinct role of subnational governments such as states and provinces in addressing climate change has been increasingly acknowledged. But while most studies investigate the causes and consequences of particular governments' actions and networking activities, this article argues that subnational governments can develop climate action as a collective entrepreneurial activity. Addressing many elements explored in this special issue, it focuses on the second question and identifies climate entrepreneurship in two subnational governments - the states of California (USA) and São Paulo (Brazil). Examining internal action, as well as interaction with local authorities, national governments and the international regime, entrepreneurial activities are identified in the invention, diffusion and evaluation of subnational climate policy in each case. The article draws from the recent scholarship on policy innovation, entrepreneurship and climate governance. It contributes to the literature by exploring entrepreneurial subnational government activity in addressing climate change and expanding the understanding of the effects of policy innovation at the subnational level.
\end{abstract}

Keywords Subnational governments · Collective entrepreneurship $\cdot$ Climate change $\cdot$ Policy innovation

Karen Anderton

karen.anderton@ouce.ox.ac.uk

1 OUCE, University of Oxford, South Parks Road, Oxford, Oxon OX13QY, UK

2 Grantham Institute on Climate Change and the Environment, LSE, London, UK

\section{Introduction}

The role of subnational governments ${ }^{1}$ in addressing climate change has been increasingly acknowledged in the past decade. Influential states and provinces can facilitate emission reductions and can be nimble in policy implementation where national governments falter (Chen et al. 2010; Falkner et al. 2010; Rabe 2008). They can also legislate and implement policies in areas where local governments lack resources, capacity and information to act (Anderton 2012; Van den Brande et al. 2012; Galarraga et al. 2011). This emerging role for subnational governments provides a potential alternative to or synergy with top-down and bottom-up approaches and can improve linkages between levels of government. However, a better understanding of subnational entrepreneurship in climate governance is still needed.

This article addresses a number of questions posed by the special issue, particularly contributing to a more robust conceptualisation of entrepreneurship in regional climate governance. To help navigate the conceptual fuzziness associated with the term entrepreneurship in climate governance, we argue that collective entrepreneurship can be established by a subnational government as a whole, rather than by particular individuals, through in-state, domestic and transnational activities. We aim to better understand the motivation behind, the strategies of entrepreneurship and the effect of these activities. While developing this argument, we utilise

\footnotetext{
${ }^{1}$ Here, we consider the definition of subnational governments as the "coherent territorial entity situated between local and national levels, with a capacity for authoritative decision-making" (Marks et al. 2008, p. 113). The term applies to the first immediate level of government below the national and above the local. It involves regional governments such as states, provinces, domains, territories, länder, cantons, autonomous communities and oblasts, depending on the country. Subnational governments are also distinct from 'local authorities', which includes all levels of government below the subnational.
} 
the policy innovation framework developed by Jordan and Huitema $(2014 a, b)$ to combine research that examines the cases of California (USA) and São Paulo (Brazil). An application of this framework highlights how subnational entrepreneurship drives new policy elements ('invention'), their entry into use ('diffusion') and their outcomes ('evaluation').

As demonstrated by these case studies, subnational governments are in a unique position to develop policies and to share and coordinate their efforts with other levels of government. The states of California and São Paulo, particularly, have introduced innovative legislation with binding emission reduction targets and have been taking action in the absence of a coordinated, ambitious national response (invention). They also promote their actions, seeking a profile of policy entrepreneurship domestically and internationally, supporting the argument that action in one domain influences governance initiatives elsewhere (diffusion). Finally, in both California and São Paulo, coordination between actors and agencies is enabling the implementation of the policies. Climate litigation also constitutes a key tool in ensuring that the policies and laws developed are capable of and are used for delivering emission reductions, thus, making them effective and impactful (evaluation).

This article firstly explores the characteristics of the subnational level, as well as the recent literature discussing climate governance, entrepreneurship and innovation. A short introduction to the context of both California and São Paulo is offered, which highlights some of the preliminary drivers for addressing climate change in each state. We then explore the activities that have taken place in or involving each state over the past decade, which represents their policy entrepreneurship in addressing climate change. Reflecting on the action taken by each state allows us to delineate some general observations of collective climate entrepreneurship at the subnational level; it is diffusion and the roles of coordination and litigation in making it effective.

Through the questions explored in this article, we advance the existing scholarship in at least two respects. First, while the climate governance literature recognises the important role that subnational governments can play in addressing climate change, we highlight the entrepreneurial aspect of these strategies. Second, rather than exploring the entrepreneurship of particular individuals working for or with a government, we investigate whether subnational governments can establish a collective entrepreneurship in addressing climate change, highlighting their role in the invention, diffusion and evaluation of policies and legislation. This contributes to overcoming the challenges of understanding the role of entrepreneurship in the implementation of policies.

\section{Subnational climate entrepreneurship}

This article aims to contribute to the research on climate governance and entrepreneurship by exploring subnational climate action as an entrepreneurial activity. Scholars have recognised the important role that governments play in addressing climate change. Even in an 'era of governance', governments continue to play a central role (Baker and Eckerberg 2008; Jordan et al. 2005). As Van den Brande et al. (2012, p. 5) argue: first, most multi-actor interactions still rely on governments to initiate actions, formulate priorities, coordinate efforts or legitimate their decisions. Second, governments are the only actors in multi-actor governance that have a legitimate democratic mandate to represent collective interests and be held accountable for it. Third, without governments, it is impossible to promote changes in all the societal processes that are targeted by sustainable development.

Subnational governments, in particular, are often cited as test-beds where experimental and ground-breaking policies can be tried, on a scale which prevents risk at the national scale and which if successful, could be rolled out or replicated on a larger scale (Markwell 1991; Harrington et al. 1998). Indeed, as US Supreme Court Justice Louis Brandeis famously posited, state governments can be "laboratories of innovative government' (New State Ice Co. v. Liebmann 1932). As Jordan and Huitema (2014b) highlight, policy entrepreneurs act as a missing link between experiments - both providing proof of principle and catalytic impacts. This article seeks to explore how subnational governments play this role in ways in which the local and national levels cannot. Being smaller than the nation-state, subnational governments can take more risks and innovate, and being closer to the people also allows for context to be accounted for. At the same time, being larger than the city or municipal area, more policy levers, resources and capacity to deliver are available, allowing subnational governments to affect a larger population.

The climate governance literature recognises the important role that subnational governments can play in addressing climate change. This literature focuses on the causes, processes, and consequences of particular subnational governments' actions (Engel 2006; Rabe 2008; Selin and VanDeveer 2009, 2011; Anderton 2012; Gordon 2015). It also examines the drivers and outcomes of their transnational and networking activities (Van den Brande et al. 2012; Setzer 2014; Schreurs 2008). In some jurisdictions, federal inaction is identified as a driver of subnational action. This is observed in the case of climate policies in the USA (Rabe 2007; Engel and Orbach 2008; Snyder and Binder 2009) and in Brazil (Romeiro and Parente 2011; Setzer 2013). Less attention, however, is given to the entrepreneurial aspect of subnational strategies.

When looking at the entrepreneurship literature, scholars tend to investigate the role of policy entrepreneurs, that is, individuals who seek to initiate dynamic policy change (Mintrom 1997), or who are "willing to invest their resources in return for future policies they favour" (Kingdon 2003, p. 117). These can include academics, think tanks, private sector leaders, government committee staffers, budget analysts and 
policy officers. The emerging literature also suggests that entrepreneurs may create links between different levels and spheres of climate governance (Boasson 2015). But while the capacity of nation-states to engage in policy innovation has been acknowledged (Jordan and Huitema 2014a, b), subnational governments rarely figure in the entrepreneurship literature as drivers of invention, diffusion and innovation. As Ralston (2013, p.2) points out, the entrepreneurial activities of the subnational level are currently not widespread knowledge.

In considering the characteristics of entrepreneurship identified in the literature, it is clear that they can apply uniformly to individuals or to a collective. Innovativeness, taking risk and being proactive are seen as being the underlying dimensions of entrepreneurship (Covin and Slevin 1991). Characteristics such as rationality, the ability to see new possibilities offered by the evolving historical situation and a desire to 'make a difference' are also seen as important (Doig and Hargrove 1987). Weissert (1991) suggests that they do so by raising awareness of issues and moving them from incubation to enactment. Engaging in dissemination and demonstration activities, collaboration with elites and gaining media attention are also facets of entrepreneurship suggested by Roberts and King (1991). More recently, Jordan and Huitema (2014a, b) also highlighted innovation as an important component of policy entrepreneurship - individual or collective. Capturing the characteristics outlined above, they suggest that innovation can be understood in terms of three perspectives, namely invention, diffusion and evaluation. Invention involves the development of policies, new or, most commonly, those that arise through processes of succession. Diffusion involves the investigation of what motivates states to emulate one another, as well as learning in and via networks. Evaluation or impact is concerned with the effects of policy innovation.

Therefore, here, we argue that the collective strategy to drive policy innovation can be attested to an entire subnational government, rather than to particular individuals. This article is concerned with subnational governments' collective entrepreneurship in addressing climate change, that is, the invention, diffusion and evaluation of climate actions that can be attested to a level of government, and all of its constituents (individual and organisational). Conceptually, a collective entrepreneur can withstand individual personnel changes if the invention stage is successful, and thereby, effort can be focused on maximising diffusion and the positive effects and impact of the policies and governance regimes that ensue.

Part of the rationale for focusing on collective entrepreneurship is in understanding that as issues become more complex, there is a need for groups to supplant individuals as the primary unit of analysis (Roberts and King 1996, p. 15). Indeed, the starting point for many in the field of environmental leadership (Rittel and Webber 1973; Gallagher 2012; Ney 2009 ) is to describe the complex nature of the challenges under consideration. Environmental challenges such as climate change involve long times to solutions, complex interactions of components and people, a weak and scattered science base, a need for interaction across disciplines to understand or solve them and an atmosphere that is emotionally charged and contentious (Gordon and Berry 2012). Considering entrepreneurship as a collective - rather than individual - effort is also justified by the concomitant existence of different types/scales in addressing climate change. Zito (2000), for example, suggests that in the EU context, a 'collective entrepreneurship' helped promoting substantial policy change. Collective entrepreneurs-Member States, the Parliament, or the Commission - pursued policy ideas that led to a revision of climate change policy goals. This work is useful to understand subnational climate entrepreneurship.

We utilise Jordan and Huitema's (2014a, b) framework to explore and compare the collective climate entrepreneurship characteristics displayed in California and São Paulo. The use of this analytical framework is justified by the fact that it enables the exploration of particular activities within the governance process. When working with two existing studies, as this article does, such a framework is useful to harmonise and compare discrete datasets. However, while Jordan and Huitema (2014a, b) suggest that policy entrepreneurship largely takes place at the invention stage, here, we assert that policy diffusion and evaluation are equally important. Indeed, there is a need for further knowledge on actual or potential effects of climate policies and, more specifically, to understand the effects of policies adopted by subnational governments (Trencher et al. 2016).

In seeking to address these knowledge gaps, we examine each tenet of the innovation process outlined by Jordan and Huitema and expand upon the evaluation stage by also exploring the role that climate litigation can play as a means of making climate policy more effective. Because subnational governments can be held accountable in courts for implementing enacted regulation, regulatory or 'promotive' climate litigation can be used in a strategic fashion to enforce climate legislation and prompt wider policy change (Peel and Osofsky 2015). This paper explores how such litigation is being used as a tool to make climate policy more effective.

\section{Approach}

This comparative study was initiated by combining separate studies with similar research questions and themes relevant to climate governance, which examined California and São Paulo, respectively. A key driver for comparing these particular states and selecting collective subnational government entrepreneurship as a focus was the identification of a number of similarities that warranted further consideration. Opting for such an approach enabled an in-depth examination of the similarities and differences in actual experiences across contexts. Indeed, political science values such case study research for 
allowing scholars to understand meaningful characteristics of real life events, furthering our knowledge of individuals, groups, organisations and social, political and related phenomena (Yin 2009). A desire to further explore the entrepreneurial activities of each state, with a view to unpacking insights around collective entrepreneurship in regional climate governance more generally, led to the data gathered in the previous studies being combined, harmonised and updated.

The original study of California was designed to understand the policy processes and leadership of the subnational government in addressing climate change with a particular focus on transport emissions. It was one of four cases in a larger comparative study (Anderton 2012). It involved semistructured interviews with some 20 relevant policy stakeholders in the state, national and local governments, as well as civil society and academic participants, which were carried out in 2009-2010. State government representatives from transport and climate change departments directly involved with the chosen policy were primary interviewees. Additional interviews were conducted with local and national government representatives, with state government representatives not directly involved with the policy, and with academic, industry and NGO actors. Themes such as leadership and process were identified to frame and analyse the findings of the research, and these delineations were helpful to transfer the relevant elements of the original research into the comparative study in this article.

The original study of São Paulo explored the international environmental relations undertaken by the state (Setzer 2013). The empirical data informing the research was gathered through participant observation and semi-structured interviews carried out in 2010-2011 with 46 figures involved with environmental governance. The individuals interviewed represented the state level (i.e. São Paulo's environmental agency), the national level (i.e. diplomats and representatives from the Environment Ministry) and NGOs, universities and the private sector. The interviews were carried out with politicians from parties across the political spectrum, NGO representatives that traditionally present a strong opposition to the government and NGO representatives that often work in partnership with the government. Also in this case, subnational leadership was a theme constantly brought up by the interviewees in explaining both the drivers and outcomes of São Paulo's paradiplomatic agenda. More specifically, the state's leadership in environmental and climate policies and legislation was identified in the research findings as a vital component of São Paulo's international relations.

It was possible to take the similar themes identified in both studies and input data from them into Jordan and Huitema's (2014a, b) framework to consider the climate entrepreneurship and innovation in each respective case study. Moreover, given that both studies used semi-structured interviews as their research method, it was possible to utilise data deriving from different questions and issues. Although the initial questions were not identical, semi-structured interviews allow for direct comparison across contexts. In other words, while the initial focus of each of the studies differed slightly, the information that was gathered enabled a sufficiently broad understanding of each policy landscapes for the similarities and differences in climate policy entrepreneurship (invention, diffusion and evaluation) between the cases to be identified.

\section{Innovation in subnational climate entrepreneurship - comparing California and São Paulo}

Subnational entrepreneurship is observed within states, between states but also transnationally, as a result of the international agenda that many regional governments undertake. The state level is responsible for the majority of policy innovation and activity related to climate change both in the USA (Rabe 2008; Matisoff and Edwards 2014) and in Brazil (Romeiro and Parente 2011). The states of California and São Paulo, in particular, are somewhat unique in this respect. They have both built a reputation of leadership in the development and adoption of climate policies in their respective countries (Biderman 2011, p. 229; Coelho and Guardabassi 2007; SMA 2011), and also internationally. This is perhaps the most relevant similarity between these two states in this study. However, there are a number of other important characteristics shared by both states that warrant further consideration. Both have a population comparable with entire nations, both are responsible for a large share of the national economic production, both face serious air pollution problems and both are significant GHG emitters in their respective countries (see Table 1 for comparison). These factors have contributed to the formulation of California's and São Paulo's entrepreneurial environmental and climate action.

While the narrative of the activities undertaken by California and São Paulo here is not exhaustive, there are major and distinct areas in which entrepreneurship can be identified in both states around climate change law and policy. These actions allow us to delineate some general observations about the development of collective climate entrepreneurship at the subnational level. In both states, it is possible to track examples of invention, diffusion and evaluation of policies, which are explored in more detail below.

\section{Establishing ambitious legislation and action plans (invention)}

Within the spectrum of innovation, the term invention is used to describe the development of something that is entirely new, that is not used anywhere else in the world (Jordan and Huitema 2014a, b). Since the 1970s, both states have been 
Table 1 Comparing California and São Paulo

\begin{tabular}{lll}
\hline & California & São Paulo \\
\hline Location & South-west USA & South-eastern Brazil \\
& $423,970 \mathrm{~km}^{2}$ & $248,209 \mathrm{~km}^{2}$ \\
Population & 38 million (2013) & 42 million (2014) \\
GDP & $\$ 2.05$ trillion (13\% US GDP, 8th economy & $\$ 0.4$ trillion (33\% of Brazilian GDP, 19th economy \\
& in the world) & in the world) \\
Emissions (date prelegislation) & $474,500 \mathrm{GgCO}_{2}$ eq in 2004 (CARB 2008) & $139,811 \mathrm{GgCO}_{2}$ eq in 2005 (CETESB 2011) \\
Breakdown & Transport (38\%) & Energy (57\%-inc. transport) \\
Legislation (mandatory and economy-wide) & AB32 (2006) Global Warming Solutions Act & Law 13,798 (2009) \\
Focus & Transportation; cap-and-trade & Renewable fuel; reporting \\
\hline
\end{tabular}

legislating and implementing innovative and ambitious policies to promote environmental protection. ${ }^{2}$ In California and São Paulo, the governments' entrepreneurship to invent policies to reduce emissions has been borne through necessity due to the severity of the problem and also lack of response by the national government. Both states have been vocal about the importance of their advocacy roles in relation to this national inaction. With statements like "Washington is asleep at the wheel [...] we know we can't count on leadership there." (SF Gate 2008) and "Brasilia has been extremely cautious [...] but São Paulo leads the way, showing that regional governments must participate in global climate governance" (FSP 2009), California's and São Paulo's entrepreneurial intentions were made clear.

Leadership itself constitutes a bond between the two governments. A Memorandum of Understanding (MOU) entered between the two states in 2005 recognises São Paulo and California "are leaders in adopting policies related to climate change"California by establishing targets and leading governments to adopt policies related to climate change, and São Paulo by seeking recognition as the first subnational government from a developing country to adopt reduction targets. Policymakers often refer to or compare São Paulo's position in Brazil with that of California in the USA - calling it "the South American 'California'3 or the "equivalent to California in Brazil'". 4

To date, the most innovative aspect of both states' efforts to mitigate climate change is the legislation they have passed. California's flagship climate law, AB32, was introduced in 2006 and was the first programme in the country to take a

\footnotetext{
2 This activity has been undertaken by both states within their constitutional competences. As subunits of federative countries, California and São Paulo have their own state constitutions and have a legislative branch, which enacts state statutes. In the USA, states retain plenary power to make laws covering anything not preempted by the federal constitution, federal statutes or international treaties ratified by the federal senate. In Brazil, the 1988 Constitution establishes an administrative decentralisation, which allows the national government, the federated states and the municipalities to engage in environmental issues.

${ }^{3}$ Interview with an official from São Paulo state government (Brazil), November 2010 .

${ }^{4}$ Interview with a national official (Brazil), December 2010.
}

comprehensive, economy-wide, long-term approach to addressing climate change. It requires California to reduce its GHG emissions to 1990 levels by 2020 - a reduction of approximately $15 \%$ below emissions expected under a "business as usual" scenario. São Paulo's flagship climate legislation is Law 13,798 of 2009, which institutes the State Policy on Climate Change. This law established a mandatory state $\mathrm{CO}_{2}$ emission reduction target of $20 \%$ on 2005 levels by 2020. Significantly, this was the first binding legislative target to appear in a non-Annex 1 country.

California's mandatory state-wide cap on emissions was the first of its kind. Its delivery document - the 'Scoping Plan' asserts that with AB32 California “is exercising a leadership role in global action to address climate change" (CARB 2008). Similarly, establishing a mandatory and economy-wide GHG reduction target, secured São Paulo's place at the forefront of climate policy and legislation in Brazil (Setzer 2014). It justified Lucon and Goldemberg (2010) calling São Paulo "the 'other' Brazil".

California and São Paulo’s focus on mitigation reinforces Mintrom and Vergari's (1996) assertion that entrepreneurship takes place where there are unfulfilled needs and where there are new possibilities offered by the evolving historical context (Doig and Hargrove 1987). Focusing primarily on the energy and transport sectors, the states can make headway in tackling the complex policy problems afoot, without taking on too much risk (though AB32's scope has expanded beyond these to become more economy-wide). In the long-term, responses will likely need to evolve to tackle a broader array of sectors and to work more concretely to understand the risks and adaptation responses required. ${ }^{5}$

\footnotetext{
${ }^{5}$ So far, there have been limited efforts to promote adaptation policies. In California, work on adaptation was confined to describing actions that could be carried out by state agencies and were considered fiscally and technologically feasible (Bizikova et al. 2014). The California Climate Adaptation Strategy was released in 2009 emphasises the need to prioritise adaptation strategies that modify and enhance existing policies, rather than those that require new funding and staffing (California Natural Resources Agency 2009). In São Paulo, a draft of the Participatory Climate Change Adaptation Plan, another requirement of the 2009 Climate Law, is still being discussed.
} 
The development or 'invention' of AB32 and Law 13,798 can be understood as 'inherently disruptive processes' (Jordan and Huitema 2014a, p. 718) in their respective territories. These two acts were sponsored by civil society organisations to get them on the legislative roster-moving them from incubation to enactment (following Weissert 1991). Both received bi-partisan support and both deliver medium-term goals, which will be realised several electoral cycles into the future. Furthermore, both laws experiment and innovate with new and established policy measures, and try to bring diverse policymakers together. In short, the legislative acts passed by California and São Paulo fulfil many of the entrepreneurial characteristics outlined in the literature.

\section{Working with local authorities, other subnational governments and the national government (diffusion)}

An important aspect of subnational entrepreneurship is coordinating and collaborating action with other levels of government. Such coordination with local authorities, other subnational governments and the national government constitutes an opportunity for policy diffusion. Diffusion refers to the process through which inventions circulate and enter into common use, via processes of learning, transfer and adoption (Jordan and Huitema 2014a, p. 720). Diffusion to municipal/ local authorities, as well as with other subnational governments and the national government, can be viewed as a challenge that subnational governments face when implementing their own climate policies - in taking their policies from invention to evaluation, diffusion can play a very significant role. In these examples, we see three types of policy diffusion at work. Firstly, with local authorities within the states - as often the implementation of state policy relies on local government (Anderton 2012), secondly with other states and thirdly with the federal government. The "International agenda (diffusion)" section will also explore policy diffusion but considers the international dimension.

Diffusion of subnational climate policy and legislation often directly impacts areas of jurisdiction that are within the purview of local authorities. In implementing AB32, a raft of supporting legislation was introduced to enable emission reduction in particular sectors. Taking SB375 as just one example, whereby California identified that transformational steps were needed to decouple transport emissions from sprawl. To do so, the state set to make a link between transportation funding, land use development and climate change. This development saw the Californian government becoming involved with issues of land use development, a 'sacred"6 area of policy traditionally overseen at the local (city or county) level. While SB375 was initially met with resistance from some cities and counties, it eventually received support from

\footnotetext{
${ }^{6}$ Interview with California state official, April 2009.
}

both the League of Cities and the California State Association of Counties. Furthermore, the state and Metropolitan Planning Organisations started working together to navigate their way through the changes resulting from SB375 and to adopt measures to bring about emission reductions, which can be considered an innovative development (Anderton 2012). That these levels of government are collectively working together to adopt and implement policy in collaboration demonstrates diffusion in action.

In Brazil, coordination between subnational and national action is prescribed by the 2009 National Climate Change Law (Law 12,187), which establishes implementation through sectoral plans, including transport and energy, directly affecting subnational policies. São Paulo's climate change law also promotes decentralisation of climate policy-making from the regional to the local level. Gradually, there have been some attempts to coordinate São Paulo's state policy with the implementation of other municipal climate policies, particularly in the city of São Paulo. For example, technical staff from both the city and state share information and data, and communication was facilitated after the state government established the GHG emissions public registry system. Nevertheless, the situation that prevails is still one of weak coordination between the states and local authorities, a factor that contributes to insufficient or inefficient implementation efforts of climate policies (Puppim de Oliveira 2009; Setzer, 2013).

Diffusion of subnational climate policy and legislation to other subnational governments is observed in opportunities for inter-state collaboration. California has engaged in a number of activities in collaboration with other US states concerning climate change. ${ }^{7}$ Perhaps the most prominent example is the Western Climate Initiative (WCI), formed in 2007 by a coalition of state governors ${ }^{8}$ looking to develop a multisector market-based mechanism to reduce GHG emissions. With the passage of AB32, California's cap-and-trade programme linked with partner schemes allied with WCI, and more recently, the programme linked with schemes in Québec and Ontario. The collaboration initially witnessed through the establishment of the WCI was seen as a significant subnational response to federal inaction both in Canada and the USA. The developments that have been achieved since, both within California, but importantly through the transnational linkages that have been made through bringing the trading schemes together, represent a significant example of policy diffusion. The subnational cap-and-trade scheme has become an interesting test bed example of the ways in which subnational governments can work together to achieve scaled responses to tackling climate change.

\footnotetext{
${ }^{7}$ In Brazil, there are no multi-state initiatives comparable to the WCI. The state of São Paulo engages with other Brazilian states mostly through the Brazilian Association of State Entities of Environment (Abema).

${ }^{8}$ Arizona, California, New Mexico, Oregon and Washington.
} 
Yet as Jordan and Huitema (2014b) noted, invention does not always necessarily lead to improvement, and the same may be true of diffusion in this context. The ABC'Anyone But California' rule was highlighted by a participant explaining that while some states will certainly emulate (parts of) what California, there are other states that "want to know that someone who's not so different as California has also done something before they are interested in trying". 9 This suggests that innovative entrepreneurial activities do not guarantee diffusion; they may be too 'radical and disruptive' (following Fagerberg 2005 in Jordan and Huitema 2014b).

Furthermore, where the appetite for the scaling up of climate action is present, it is conceivable that state-based or led initiatives could lead to diffusion to the national level. There are certainly examples in both cases where state action has been diffused to the federal government and as a result becomes applicable to all states. California has been described as a 'super-regulator', particularly around vehicle emission standards - typically California enacts ambitious standards that the federal government follows suit on years later (Carlson 2008). Similarly, São Paulo has been described as a standard setter in Brazil. In relation to the national climate policy, São Paulo's Climate Law has arguably triggered action at the national level (Romeiro and Parente. 2011; Lucon and Goldemberg 2010). The same argument that São Paulo's legislation played a key role in advancing the national policy was made by a number of relevant actors interviewed at the state and at the federal level. ${ }^{10}$ However, the potential for scaling up also depends on the national level's support for climate-related activity. If climate change is not considered a priority of an administration, it is unlikely that climate policies coming from the states will be diffused to the national level. In this case, states will remain reliant on entrepreneurship at and diffusion between subnational entities.

\section{International agenda (diffusion)}

Undertaking an international climate agenda is a key component of subnational entrepreneurial strategy. It can

\footnotetext{
${ }^{9}$ Interview with US national official, May 2009.

10 The Brazilian federal government approved its National Climate Change Policy on the 29th of December 2009, 6 months after the city of São Paulo, and almost 2 months after, the state of São Paulo enacted their municipal and state climate policies. The national policy, on the one hand, established a "voluntary commitment" to adopt mitigation actions for GHG emissions that reduce between 36.1 and $38.9 \%$ of projected emissions by 2020 (article 12). The state and the city, on the other hand, established mandatory reduction targets of 20 and $30 \%$, based on their 2005 inventory of emissions. In this view, the climate laws enacted by the city and the state of São Paulo not only broke the national inaction, but, establishing a mandatory (not voluntary) goal, and in establishing the reduction of $\mathrm{CO}_{2}$ emissions in absolute terms (not only a deceleration or a decrease per unit of GDP), they continued to be more ambitious than the national legislation.
}

involve the establishment of bilateral or multilateral partnerships, participation in transnational networks and engagement in the international climate regime (Setzer 2013). Subnational governments use these opportunities to promote the diffusion of their policies and actions, be it establishing technical, scientific, technological and financial exchanges, presenting their leading climate action to a wide international audience or engaging in the international debate.

Through their respective international agendas, California and São Paulo are vocal about their diffusion activities, sharing their domestic achievements and seeking to promote their reputation as climate leaders. Before his re-election into office in November 2014, Governor Brown stated: "California has the most integrated response and strategy to deal with climate change of any political jurisdiction in the world [...] What happens here doesn't stay here, it goes all around the globe" (Thompson 2014). In São Paulo, the climate law was promoted as having "no precedent in the developing world and stands as the most far-reaching climate policy initiative on the subnational level in a developing economy" (Lucon and Goldemberg 2010, p. 348).

Both California and São Paulo have a history of establishing bilateral or multilateral partnerships with other national or subnational governments and international organisations. For instance, for over 20 years, California has maintained such partnerships with Bavaria to promote renewable energy technologies and environmental management systems and with North Rhine-Westphalia to advance clean energy technologies, especially hydrogen and fuel cells (Ralston 2013). In São Paulo, both the state environmental agency and the state Secretariat for the Environment have signed agreements with a number of international organisations, including the United Nations Development Programme (UNDP), the World Health Organisation, the World Bank and the German Federal Environment Agency (UBA), amongst others.

Bilateral partnerships have also been established between California and São Paulo. The first partnership was established in 2005, during COP-11 in Montreal, with an MOU entered into between São Paulo's environmental secretariat and California's Environment Protection Agency. The MOU aimed to promote climate change mitigation with a focus on transportation and technical cooperation in the areas of renewable energy sources, environmental improvement, climate change and biodiversity. This agreement stated that both states had the intention to "play leading roles in the global effort to reduce greenhouse gas emissions" (CalEPA 2005). The two states have also worked together to promote the importance of the subnational government in advancing climate change responses globally. In 2009, at COP-15 in Copenhagen, São Paulo Governor José Serra and California Governor Arnold Schwarzenegger organised a joint side-event. 
Indeed, California and São Paulo regularly attend UNFCCC conferences, and the leadership role they play in climate policy-making opens doors for their participation. California has actively participated in many events taking place alongside the formal international negotiations since 2005. For example, in 2006 in Nairobi, then-CalEPA Secretary Linda Adams reported to the Plenary on behalf of convened states and regions calling on the delegates to formally recognise subnational governments and to open up the negotiations to actors below the national level. In São Paulo state officials justify participation on the basis that "it is crucial that we go [to international meetings] and present what we are doing.... If we don't, other regions won't know that we have a model that can be followed." ${ }^{11}$ São Paulo's officials also want to influence the Brazilian position and eventually the outcome of international environmental negotiations (Setzer 2015). Representatives from the state of São Paulo speak as governmental representatives, as they have robust technical knowledge and experience in environmental policymaking. São Paulo's international advisor gives a clear account of this motivation:

We want to promote the state of São Paulo as an international reference. It is a matter of image. But it is also important for us to have our own interests incorporated into the international legal frameworks. We don't want to be mere policy implementers. We want to make clear what is good for us and to inject São Paulo's view in the international debate in order to satisfy our own interests. $^{12}$

Finally, participation in transnational networks has been central in establishing the entrepreneurship of both these governments and in facilitating the international platform for such events. California is a founder of R20, and São Paulo is a founder of the Network for Regional Governments for Sustainable Development (nrg4SD), and the two states are both active members of The Climate Group (TCG). These networks explicitly advocate that subnational governments are laboratories for future national policy, and that they should push their respective national governments into more rapid actions and stronger commitments to fight climate change (R20 2013; nrg4SD 2011; TCG 2016a). Following the Paris Climate Agreement in 2015, California hosted the first Subnational-Clean Energy Ministerial event in June 2016-a ministerial level summit for cities, states and regions, offering the opportunity to exchange experiences and information (TCG 2016b). Such activities demonstrate that diffusion is an important element of subnational climate entrepreneurship.

\footnotetext{
$\overline{11}$ Interview with a state official (São Paulo), December 2010.

${ }^{12}$ Interview with a state official (São Paulo).
}

\section{Implementation and beyond (evaluation)}

It is important to note that developing and enacting legislation and promoting the diffusion of the lessons learned is only the beginning. In addition to these activities, subnational governments need to be concerned with the implementation of the law and policies created. While the approval of the laws in California and São Paulo was a successful inventive effort, which involved governmental and non-governmental stakeholders across different organisations, the implementation of these instruments requires unprecedented levels of cooperation and coordination within and beyond each government's structures.

In California, AB32 established a Climate Action Team, a cross-administration group, and required that "every agency, department and division will bring climate change considerations into its policies, planning and analysis" (CARB 2008). Since its enactment, the law continues to enjoy bi-partisan, cross-party and long-term support. The initial implementation measures have been facilitated through rafts of supporting legislation, and it has also survived formal attempts to halt its progress. Ahead of the 2010 state election, proposition 23 attempted to suspend AB32, but it was voted down, highlighting broad-base support for the bill and a major triumph for climate change policy in the USA — and ensured implementation of the Scoping Plan would progress as planned towards meeting the 2020 and 2035 reduction targets (Anderton 2012). More recent developments include the introduction of the capand-trade scheme and Executive Order B-30-15, which established an emission reduction target of $40 \%$ below 1990 levels by 2030 . The case of California indicates that, with collective entrepreneurship, the passage of legislation can sustain continuing policy change (Mintrom 1997).

In São Paulo, the implementation of the state's climate law is generally taking a slower pace. The state developed only a few strategies, including a biofuels programme and the Climate Protocol. Both these initiatives are voluntary and established in partnership with businesses. The Climate Protocol, for example, is based on a progressive system of points attributed through the information provided by the companies and does not establish mandatory reduction targets. The case of São Paulo suggests that, while subnational climate entrepreneurship can lead to initial important achievements, such as the passage of ambitious legislation, not even the historical entrepreneurship of the state and the hard work of policy entrepreneurs might be sufficient to sustain continuing policy change. As Mintrom (1997) also recognises, policy entrepreneurs, like other actors in the policy-making process, must be aware of the constraints imposed by election cycles and interest group opposition to their proposals.

Yet, innovative mechanisms can be established to address the challenge of implementing ambitious commitments. In the 
transnational climate governance literature, scholars have described the use of self-monitoring and self-verification as means for promoting evaluation of climate action adopted by subnational governments (Bulkeley et al. 2012). The cases of California and São Paulo suggest that litigation can constitute another option to assess the consequences of a given policy innovation and, moreover, offer an option to enforce legislation where non-compliance becomes an issue. Subnational governments can be involved as plaintiffs or respondents in court cases dealing with climate legislation development and enactment. In fact, climate change litigation has been understood as a catalyst for action (Fisher 2013, p. 241). In some cases, climate litigation can promote legal change and help change social and business norms in ways that motivate action by governments and other key stakeholders (Peel and Osofsky 2015).

Subnational climate litigation, in particular, can be used by subnational governments in response to a dearth of national climate legislation, as well as against subnational governments, to pursue or contest the implementation and enforcement of climate legislation. Subnational climate litigation can constitute a key tool in ensuring that the policies and laws that are developed are capable of and are used for delivering emission reductions, thus, making subnational policies effective or impactful, fulfilling the third pillar of Jordan and Huitema's (2014a, b) framework. Through subnational climate litigation, Osofsky (2007, p. 13) argues, '[states and localities] help to move the dialogue on climate regulation forward'.

In California, litigation has been increasingly utilised as a tool to navigate issues arising as climate change policy develops. The case of Massachusetts v. EPA (2007), in which the state of California acted as one of the petitioners, was significant across the USA, because it ruled that petitioner states have standing to bring action and also that the EPA has the authority to regulate GHGs under the Clean Air Act. Litigation has subsequently been used in California. Cases such as People of California vs. County of San Bernardino (2007) and People of California vs. City of Pleasanton (2009), both addressed the failure of the local governments to analyse GHG impacts in their general plan updates. But the state has also been legally challenged, by both industry and by civil society, ${ }^{13}$ for the policies and laws it has put in place to address the issue.

In São Paulo, climate litigation is incipient, but it could become, like in California, a relevant tool to navigate the policy and legal responses that are being developed to tackle reduce emissions. Particularly, since the Brazilian legislation provides for the polluters pay principle and a 'strict liability',

\footnotetext{
${ }^{13}$ For industry see, for example General Motors Corp. v. California Air Resources Board, Fresno County Superior Court No. 05-02787. For civil society see, for example, Association of Irritated Residents et al. v. California Air Resources Board, San Francisco Superior Court, Case Number CPF-09-509562 (2011).
}

meaning that it is unnecessary to demonstrate that the defendant meant to cause harm. One of the most interesting cases taken to the state Court of Justice is a class action filed by the state Prosecutor's Office against 40 airplane companies operating in the international airport of São Paulo for the emissions and pollution caused during landing and departures. In its decision, the state court acknowledged the environmental damage resulting of airplanes landing and departure, calling the companies to be liable for reforestation of the area around the airport. ${ }^{14}$ Moreover, the state public prosecutors are entitled by the constitution to defend environmental interests and call for the enforcement of existing legislation which is not being implemented, so it might be a matter of time until they call the state in courts to inquiry the state on the achievement of the reduction targets established by the state climate law.

Therefore, litigation can constitute a mechanism in subnational climate entrepreneurship to ensure that climate laws become effective. Whether lawsuits are used against subnational governments when targets and goals established in legislation are not met, or whether they are used by subnational governments against big emitters or the national government, litigation can help to ensure that challenges to implementation are held to account. After all, climate policies can only be 'impactful' if they are implemented and lead to emission reduction. Holding entities that prevent this to account through litigation will probably become more important in the coming years.

\section{Conclusion}

Considering the constituent elements of innovation, this article used a comparative case study approach to explore the collective entrepreneurial strategies that subnational governments can undertake to address climate change. A number of similarities are clear in the subnational climate entrepreneurship that California and São Paulo have displayed over the past decade. Both states sought mandatory reduction targets out and legislated accordingly, and both established platforms to promote their own work and advocate for similar and enhanced responses at scale. Longer-term visions have been set, and mechanisms are evolving to deliver against these aims. This entrepreneurial strategy was established through in-state, domestic and transnational activities and can be attested to these subnational governments as a whole, rather than to particular individuals.

Clearer differences, however, are observed in the means through which entrepreneurial action is sustained. While both

\footnotetext{
${ }^{14}$ More information about the decision can be found at the following:

http://www.mpsp.mp.br/portal/page/portal/procuradoria_interesses difusos coletivos/Noticias/TJ\%20acolhe $\% 20$ recurso $\% 20 \mathrm{do} \% 20 \mathrm{MP} \% 20 \mathrm{e} \%$ 20reconhece $\% 20$ impacto\%20ambiental $\% 20$ produzido $\% 20$ por $\% 20$ avi $\% \mathrm{C} 3 \%$ B5es\%20no\%20Aeroporto\%20de \%20Cumbica.
} 
climate legislations were enacted, in California the cap-andtrade scheme has been operationalized, extended to link with Canadian Provincial schemes via the WCI. California's scoping plan and supplementary legislation have been introduced to achieve the interim targets laid out in AB32, and the state is working together with local authorities to deliver emission reductions. The initial collective entrepreneurship to get AB32 passed is extending into the other phases of innovation. In São Paulo, however, the emphasis on enacting the legislation and the resources to support the achievement of the targets has been weaker. Although rigorous and thorough, the state Climate Law is not being sufficiently enforced. Challenges to enforce the new legislation include limited capacity of regulatory agencies in terms of staff, technical expertise, financial resources and political will. As a result, after 7 years of its enactment, the law still lacks implementation. Further study is required to unpack the reasons for the differences in experiences and outcomes in the implementation of the laws in both states.

However, even if unenforced, ambitious and innovative subnational policies still have their merits. First, they demonstrate that subnational governments can be proactive in addressing climate change. Such proactivity is especially interesting in cases where the national government lacks leadership (as observed in both cases) and when observed in subnational governments from emerging economies (in the case of São Paulo). Second, the relevance of climate actions is not completely dependent on the amount of GHG reduced. Rather, "the ultimate goal of climate action is redirection of the economy and society onto a low-carbon pathway" (Hoffmann 2011, p. 107). Third, to avoid that lack of enforcement undermines the subnational entrepreneurship that successfully established the law, the content of the law can be enforced in courts. Through climate litigation, subnational governments can be called to make the commitments effective and keep up with their entrepreneurial position and turn rhetoric and strategy into action.

In this analysis, Jordan and Huitema's (2014a, b) innovation framework provided a useful analytical tool to explore subnational entrepreneurship in greater detail. It offered themes in which data from distinct studies around subnational climate governance could be synthesised. While it could be considered a limitation that the data came from studies with similar, but not identical foci, combining these studies enabled valuable insight about subnational climate entrepreneurship to be derived. It allowed us to understand that California and São Paulo have invented and diffused innovative climate policy and demonstrated entrepreneurial approaches to varying degrees. The governments of the two states have collectively engaged in actively identifying problems and have framed their climate change agenda within the state, nationally and internationally. Additionally, both have engaged in dissemination and demonstration activities and gaining media attention. Further contributing to the framework, this article provided insight into the evaluation phase of innovation. In promoting policy innovation, diffusion and evaluation are just as important, if not more, than invention. The cases of California and São Paulo highlight that litigation can constitute an additional option to make policy innovation more effective by providing an option to enforce legislation where non-compliance or lack of implementation becomes an issue.

With the Paris Agreement incorporating a bottom-up approach, based on individual nationally determined contributions (INDCs) rather than imposed targets, it is clear that much can be learned from the climate change entrepreneurship that has been developed at the subnational level, in states like California and São Paulo. National policies and institutions can also contribute to subnational entrepreneurship, helping to ensure that the goals and targets set are actually implemented. The new global climate policy regime has been invented; there is now an international imperative for diffusion and evaluation to follow. It is important that studies such as this help to promote the significance of collective responses, demonstrating that the other elements of innovation - diffusing ideas and working across levels to facilitate effective emission reductions - are of paramount importance.

Acknowledgements Our warm thanks to the participants at the Policy Entrepreneur Workshop (Amsterdam, May 2015) and particularly Dave Huitema, Andy Jordan, Elin Lerum Boasson and Raoul Beunen for the very helpful comments to earlier versions of this manuscript. We are also grateful to the two reviewers from Regional Environmental Change for their constructive comments.

Open Access This article is distributed under the terms of the Creative Commons Attribution 4.0 International License (http:// creativecommons.org/licenses/by/4.0/), which permits unrestricted use, distribution, and reproduction in any medium, provided you give appropriate credit to the original author(s) and the source, provide a link to the Creative Commons license, and indicate if changes were made.

\section{References}

Anderton K (2012) Sub-national government responses to reducing the climate impact of cars. Dissertation, University of Oxford, Oxford

Baker S, Eckerberg K (eds) (2008) In pursuit of sustainable development: new governance practices at the sub-national level in Europe. Routledge, New York

Biderman R (2011) Limites e alcances da participação pública na implementação de políticas subnacionais em mudanças climáticas no municipio de São Paulo. (PhD). Fundação Getulio Vargas, São Paulo

Bizikova L, Crawford E, Nijnik M, Swart R (2014) Climate change adaptation planning in agriculture: processes, experiences and lessons learned from early adapters. Mitig Adapt Strateg Glob Chang 19(4):411-430. doi:10.1007/s11027-012-9440-0

Boasson E (2015) National Climate Policy: a multi-field approach. Routledge, London 
Bulkeley H, Andonova L, Bäckstrand K, Betsill M, Compagnon D, Duffy R, Kolk A, Hoffmann M, Levy D, Newell P, Milledge T, Paterson M, Pattberg P, VanDeveer S (2012) Governing climate change transnationally: assessing the evidence from a database of sixty initiatives. Environmental and Planning C: Government and Policy 30(4):591-612. doi:10.1068/c11126

CARB (2008) Climate change scoping plan: a framework for change. December $2008 \mathrm{http} / /$ www.arb.ca.gov/cc/scopingplan/document/ adopted_scoping_plan.pdf Accessed 1 May 2016

CalEPA (2005) California and São Paulo Environment Protection Secretaries Sign Climate Change Agreement, Press Release December $6^{\text {th }}$. http://www.calepa.ca.gov/pressroom/Releases/2005/ PR19-120605.pdf Accessed May 12016

California Natural Resources Agency (2009) California climate adaptation strategy http://resources.ca.gov/docs/climate/Statewide_ Adaptation_Strategy.pdf Accessed 1 May 2016

Carlson A (2008) Iterative federalism and climate change. Journal of Scholarly Perspectives, UCLA School of Law 4(01):3-13

CETESB (2011) 1st direct and indirect greenhouse gases anthropogenic emissions inventory of São Paulo state: state communication. CETESB, São Paulo

Chen L, Malaki A, Pruski J, Wang W (2010) Subnational capacity building for the next international climate change agreement. International Policy Studies Practicum, Stanford, CA

Coelho S, Guardabassi P (2007) Environmental public policies for the state of São Paulo. InterfacEHS - Revista de Saúde, Meio Ambiente e Sustentabilidade 2(4):1-19

Covin J, Slevin D (1991) A conceptual model of entrepreneurship as firm behavior. Enterp Theory Pract 16(1):7-25

Doig J, Hargrove E (1987) Leadership and innovation: a biographical perspective on entrepreneurs in government. The John Hopkins University Press, London

Engel K (2006) State and local climate change initiatives: what is motivating state and local governments to address a global problem and what does this say about federalism and environmental law. Urban Lawyer 38(4):1015-1030

Engel K, Orbach B (2008) Micro-motives for state and local climate change initiatives. Harvard Law and Policy Review 2:119-137

Fagerberg J (2005) Innovation. In: Fagerberg J, Mowery D, Nelson R (eds) Oxford handbook of innovation. Oxford University Press, Oxford, pp 1-26

Falkner R, Stephan H, Vogler J (2010) International climate policy after Copenhagen: towards a 'building blocks' approach. Global Policy 1(3):252-262. doi:10.1111/j.1758-5899.2010.00045.x

Fisher E (2013) Law and policy. The University of Denver/Colorado Seminary 35(3):236-260

FSP (2009) Mudanças climáticas e São Paulo, Xico Graziano and Fernando Rei, February 17, 2009, http://www1.folha.uol.com.br/ fsp/opiniao/fz1702200909.htm Accessed 21 May 2016

Galarraga I, Gonzalez-Eguino M, Markandya A (2011) The role of regional governments in climate change policy. Environmental Policy and Governance 21:164-182. doi:10.1002/eet.572

Gallagher D (ed) (2012) Environmental leadership: a reference handbook. Sage Publications Ltd., Thousand Oaks, CA

Gordon D (2015) An uneasy equilibrium: the coordination of climate governance in federated systems. Global Environmental Politics 15(2):121-141. doi:10.1177/0263774X15614675

Gordon J, Berry J (2012) Environmental leadership equals essential leadership: redefining who leads and how. Yale University Press, London

Harrington W, McConnell V, Walls M (1998) Who's in the driver's seat? Mobile source policy on the US federal system. In: Proost S, Braden $\mathrm{J}$ (eds) Climate change, transport and environmental policy. Edward Elgar, Cheltenham, pp 131-157
Hoffmann M (2011) Climate governance at the crossroads: experimenting with a global response after Kyoto. Oxford University Press, Oxford

Jordan A, Huitema D (2014a) Innovations in climate policy: the politics of invention, diffusion, and evaluation. Environmental Politics 23(5):715-734. doi:10.1080/09644016.2014.923614

Jordan A, Huitema D (2014b) Policy innovation in a changing climate: sources, patterns and effects. Glob Environ Chang 29:387-394. doi: 10.1016/j.gloenvcha.2014.09.005

Jordan A, Wurzel R, Zito A (2005) The rise of 'new' policy instruments in comparative perspective: has governance eclipsed government? Political Studies 53:477-496. doi:10.1111/j.1467-9248.2005. 00540.x

Kingdon J (2003) Agendas, alternatives, and public policies. Longman, New York

Lucon O, Goldemberg J (2010) São Paulo, the “other” Brazil: different pathways on climate change for state and federal governments. The Journal of Environment and Development 19(3):335-357. doi:10. $1177 / 1070496510378092$

Matisoff D, Edwards J (2014) Kindred spirits or intergovernmental competition? The innovation and diffusion of energy policies in the American states (1990-2008). Environmental Politics 23(5):795817. doi:10.1080/09644016.2014.923639

Marks G, Hooghe L, Schakel A (2008) Measuring regional authority. Regional and Federal Studies 18(2):111-121. doi:10.1080/ 13597560801979464

Markwell D (1991) The Federal State: lessons from North American and European Experience", Ditchley Foundation Conference Report No. D91/11

Mintrom M (1997) Policy entrepreneurs and the diffusion of innovation. Am J Polit Sci 41(3):738-770

Mintrom M, Vergari S (1996) Advocacy coalitions, policy entrepreneurs and policy change. Policy Studies Journal 24(3):420-434

Ney S (2009) Resolving messy policy problems. EarthScan Publications, London

Nrg4SD (2011) Statutes of the Network of Regional Governments for Sustainable Development Nrg4SD, adopted by the General Assembly of Quebec, 29-31 August 2011

Osofsky H (2007) Local approaches to transnational corporate responsibility: mapping the role of subnational climate change litigation. Global Business and Development Law Journal, Vol. 20

Peel J, Osofsky H (2015) Climate change litigation regulatory pathways to cleaner energy. Cambridge University Press, Cambridge

Puppim de Oliveira J (2009) The implementation of climate change related policies at the subnational level: an analysis of three countries. Habitat International 33(3):253-259. doi:10.1016/j.habitatint.2008. 10.006

Romeiro V, Parente V (2011) Climate change regulation in Brazil and the role of subnational governments. In: Seroa da Motta R, Hargrave J, Luedemann G, Sarmiento Gutierrez M (eds) Climate change in Brazil: economic, social and regulatory aspects. Institute for Applied Economic Research, Brasilia, pp 45-57

R20 (2013) About R20. http://regions20.org/about-r20] Accessed May $1^{\text {st }} 2016$

Rabe B (2007) Beyond Kyoto: climate change policy in multilevel governance systems. Governance 20(3):423-444. doi:10.1111/j.14680491.2007.00365.x

Rabe B (2008) States on steroids: the intergovernmental odyssey of American climate policy. Review of Policy Research 25(2):105-128

Ralston H (2013) Subnational partnerships for sustainable development: transatlantic cooperation between the United States and Germany. Edward Elgar, Cheltenham

Rittel H, Webber M (1973) Dilemmas in a general theory of planning. Policy Sci 4(1973):155-169 
Roberts N, King P (1991) Policy entrepreneurs: their activity structure and function in the policy process. J Public Adm Res Theory 1(2): $147-175$

Roberts N, King P (1996) Transforming public policy: dynamics of policy entrepreneurship and innovation. Jossey-Bass Publishers, San Francisco, CA

Schreurs M (2008) From the bottom up. The Journal of Environment and Development 17(4):343-355. doi:10.1177/1070496508326432

Selin H, VanDeveer S (2009) Changing climates in North American politics: institutions, policymaking, and multilevel governance. MIT Press, Cambridge, MA

Selin H, VanDeveer S (2011) Climate change regionalism in North America. Review of Policy Research 28(3):295-304

Setzer J (2013) Environmental paradiplomacy: the engagement of the Brazilian state of São Paulo in international environmental relations. Dissertation, London School of Economics and Political Science, London

Setzer J (2014) How subnational governments are rescaling environmental governance: the case of the Brazilian state of São Paulo. J Environ Policy Plan 16(5):1-17. doi:10.1080/1523908X.2014. 984669

Setzer J (2015) Testing the boundaries of subnational diplomacy: the international climate action of local and regional governments. Transnational Environmental Law 4(2):319-337. doi:10.1017/ S2047102515000126

SF Gate (2008), Governor sees greener future for state, September 27 2008, http://articles.sfgate.com/2008-09-27/bay-area/17160078_1_ warming-emissions-greenhouse Accessed May 12016

SMA (2011) PROCLIMA — Programa Estadual de Mudanças Climáticas do Estado de São Paulo http://homologa.ambiente.sp.gov.br/ proclima/sobre proclima/historico.asp Accessed May 122016
Snyder J, Binder J (2009) The changing climate of cooperative federalism: the dynamic role of the states in a national strategy to combat climate change. UCLA Journal of Environmental Law and Policy 27(2):232-260

TCG (2016a), http://www.theclimategroup.org/who-we-are/about-us/ Accessed May $12^{\text {th }} 2016$

TCG (2016b) "Following Paris Climate Agreement, the Subnational Fight Against Climate Change Continues", $12^{\text {th }}$ May 2016, http:/ www.theclimategroup.org/what-we-do/news-and-blogs/followingparis-climate-agreement-the-subnational-fight-against-climatechange-continues/ Accessed May $12^{\text {th }} 2016$

Thompson D (2014) California leads by example on climate change. Associated Press, 13th November. http://hosted.ap.org/dynamic/ stories/U/US_CLIMATE_CHANGE_CALIFORNIA?SITE= APandSECTION=HOMEandTEMPLATE=DEFAULT Accessed May $12^{\text {th }} 2016$

Trencher G, Castán Broto V, Takagi T, Sprigings Z, Nishida Y, Yarime M (2016) Innovative policy practices to advance building energy efficiency and retrofitting: approaches, impacts and challenges in ten C40 cities, Environmental Science and Policy In Press - Available online 18 July 2016. doi:10.1016/j.envsci.2016.06.021

Van den Brande K, Bruyninckx H, Happaerts S (2012) Introduction. In: Bruyninckx H, Happaerts S, Van den Brande K (eds) Sustainable development and subnational governments policy making and multi-level interactions. Palgrave Macmillan, Hampshire, pp 1-24

Weissert C (1991) Policy entrepreneurs, policy opportunists and legislative effectiveness. American Politics Quarterly 19(2):262-274

Yin R (2009) Case study research: design and methods, Fourth edn. SAGE Publications, London

Zito A (2000) Creating environmental policy in the European Union. St. Martin's Press, New York 